\title{
PENGARUH PENDEKATAN OPEN INNOVATION TERHADAP KINERJA INOVASI PERUSAHAAN DI INDONESIA
}

\author{
Siti Fadhilah \\ Periset Muda PPM Manajemen, Jakarta \\ shiva.fadhilah@gmail.com \\ Julianita Kurnia S \\ Core Trainer PPM Manajemen, Jakarta \\ jul@ppm-manajemen.ac.id
}

\begin{abstract}
ABSTRAK
Open innovation merupakan pendekatan yang tidak hanya melibatkan internal perusahaan, tetapi juga pihak ekternal dalam mengembangkan dan mengintegrasikan ide baru secara optimal untuk kepentingan perusahaan. Pendekatan ini lebih banyak diterapkan oleh perusahaan dalam berinovasi guna mengatasi dunia bisnis yang sangat kompetitif. Namun, penelitian melalui pendekatan ini masih minim dan konsepnya belum diadopsi secara lengkap di Indonesia. Untuk itu, tujuan dari penelitian ini yaitu mengetahui bagaimana pengaruh pendekatan open innovation dan faktor-faktor pendukung perkembangan inovasi terhadap kinerja inovasi perusahaan di Indonesia. Penelitian dilakukan pada tahun 2014 dengan ruang lingkup penelitian ini adalah perusahaan Indonesia yang bergerak di seluruh sektor industri (baik sektor manufaktur dan jasa), yang melakukan aktivitas inovasi selama 3 tahun terakhir, yaitu tahun 2011 sampai dengan tahun 2013. Metode penelitian yang dilakukan adalah secara kuantitatif dengan teknik analisis data secara statistik deskriptif dan inferensial yaitu analisis regresi. Hasil penelitian yang diperoleh menunjukkan bahwa model pendekatan open innovation memiliki pengaruh signifikan terhadap kinerja inovasi perusahaan, namun hanya dua dari tiga variabel pendekatan yaitu kolaborasi antar organisasi dan akuisisi teknologi yang memiliki pengaruh signifikan. Untuk kedua faktor pendukung perkembangan inovasi yaitu sumber informasi (baik internal maupun eksternal) dan R\&D internal, faktor yang memiliki pengaruh signifikan terhadap kinerja inovasi perusahaan hanya R\&D internal saja.
\end{abstract}

Kata Kunci:

Open innovation, sumber informasi, $R \& D$, kinerja inovasi

\begin{abstract}
ABSTRACK
Open innovation is an approach that involves not only internal company, but also external parties in developing and integrating new ideas optimally for the benefit of the company. This approach is more applied by companies in innovating to cope with the business world whom very competitive. However, research through this approach is still minimal and the concept has not been fully adopted in Indonesia. Therefore, the purpose of this research is to know how the influence of open innovation approach and the factors supporting the development of innovation on innovation performance in Indonesian companies. The research was conducted in 2014 with the scope is Indonesian companies engaged in all industrial sectors (both manufacturing and service sectors), which conducts innovation activities for the last 3 years, from 2011 to 2013. The research method is quantitative with statistical data analysis descriptive and inferential ie regression analysis. The result of the research shows that the open innovation approach model has a significant influence on the innovation performance of the company, but only two of the three variables approach are inter-organizational collaboration and technology acquisition which has significant influence. For both factors supporting the development of innovation ie the source of information (both internal and external) and internal R \& D, factors that have a significant influence on innovation performance of the company only internal R \& D alone.
\end{abstract}

Keywords:

Open innovation, source of information, $R \& D$, performance of innovation 


\section{PENDAHULUAN}

Inovasi adalah mengubah atau menciptakan lebih banyak proses, produk, dan ide yang lebih efektif dalam perusahaan (Hurley et.al, 2003). Alasan utama perusahaan berinovasi adalah untuk meningkatkan kinerja perusahaan, dengan cara meningkatkan kemampuan proses produksi dalam mengembangkan berbagai produk baru, dan praktik baru di organisasi yang dapat meningkatkan kemampuan perusahaan untuk mendapatkan dan menciptakan pengetahuan baru yang dapat digunakan untuk mengembangkan inovasi lainnya (OECD dan Eurostat, 2005; Cheng, et.al, 2014; Jiménez dan Sanz-Valle, 2010). Selain itu, inovasi dalam bisnis membantu perusahaan menciptakan solusi dan langkah-langkah inovatif dalam persaingan bisnis. Adanya evaluasi bisnis pada kinerja inovasi, dapat membantu manajer untuk secara efektif menggunakan potensi inovasi dalam keberhasilan bisnis (Lendel dan Varmus, 2013). Oleh karena inovasi memainkan peran penting dalam keberhasilan perusahaan dalam memperoleh keunggulan kompetitif yang berkelanjutan, banyak penelitian telah berusaha untuk mengeksplorasi hubungan antara inovasi dan kinerja dalam beberapa tahun terakhir (Hana, 2013; Brem et.al, 2015; Farhas et.al, 2016).

Inovasi sudah mulai diterapkan negaranegara di dunia baik pendekatan yang bersifat closed innovation (menghasilkan inovasi dengan menggunakan sumber internal perusahaan) maupun open innovation (menghasilkan inovasi dengan menggabungkan sumber internal dan eksternal). Saat ini, open innovation lebih banyak diterapkan oleh perusahaan dalam berinovasi, seperti IBM, Intel Philips, Unilever, dan Procter \& Gamble karena dunia bisnis sudah lebih terbuka dan sangat kompetitif, sehingga perusahaan perlu lebih inovatif dan kreatif untuk menarik pelanggan (Chesbrough, 2012). Open innovation membantu perusahaan melibatkan semua pihak antara lain karyawan, konsumen, pemasok, dan peneliti, dalam mengembangkan ide baru untuk kepuasan seluruh pihak yang terlibat (OECD, 2008; Vanhaverbeke et.al, 2014).

Bogliacino et al., (2009) telah melakukan survei mengenai inovasi menggunakan instrumen berdasarkan Oslo Manual ke beberapa 


\section{Pengaruh Pendekatan Open Innovation terhadap Kinerja ...(Siti Fadhilah \& Julianita KS.)}

negara di Asia Timur seperti Korea Selatan, Taiwan, Singapura, Malaysia, dan Thailand. Inovasi yang dilakukan oleh 5 negara tersebut merupakan inovasi baik produk maupun proses. Pada survei yang dilakukan tahun 2004-2005 di Malaysia ditemukan bahwa, 4 dari 5 perusahaan yang melakukan inovasi dikendalikan oleh perusahaan nasional dan 2 dari 3 perusahaan tersebut relatif masih muda, melakukan inovasi pada proses dan produk yang bergantung pada sumber daya internal dan kerjasama lokal. Kegiatan inovasi juga dilakukan di Korea Selatan berdasarkan penelitian-penelitian yang sudah dilakukan. Hasil dari penelitian tersebut adalah inovasi pada proses lebih memberikan dampak terhadap produktivitas. Di negara Taiwan, sekitar $50 \%$ perusahaan sudah melakukan inovasi dan kebijakan publik secara aktif terlibat dalam pengembangan teknologi. Perusahaan yang ada di Singapura sekitar $75 \%$ sudah melakukan inovasi, sementara di negara Thailand sekitar $43 \%$ perusahaan yang ada sudah melakukan inovasi.

Menurut Global Innovation Index (GII) di tahun 2014, tingkat penerapan inovasi di Indonesia masih tertinggal yaitu peringkat 87 dari 143 negara, dibanding negara-negara tetangga seperti Singapura (peringkat 7), Malaysia (peringkat 33), Thailand (peringkat 48), dan Vietnam (peringkat 71). Selain tingkat penerapan inovasi yang tergolong tertinggal dibanding negara tetangga, konsep open innovation masih belum diadopsi secara lengkap dan baru terlihat hanya pada UKM Indonesia (Hamdani dan Wirawan, 2012; Muzamil dan Ginting, 2015). Padahal salah satu upaya yang dapat dilakukan perusahaan untuk memenangkan persaingan adalah melakukan inovasi, di mana untuk negara berkembang seperti Indonesia yang pertumbuhannya cukup signifikan yaitu persentase rata-rata pertumbuhan tahun 2000-2013 sebesar 5,77\% (Worldbank, 2014) merupakan langkah yang tepat untuk melakukan inovasi guna memenangkan persaingan pada MEA tahun 2015. Tahun 2015 merupakan tahun dimulainya MEA (Masyarakat Ekonomi ASEAN) yang berarti semakin terbukanya persaingan antar negara. Pertumbuhan ekonomi di Indonesia yang cukup signifikan dari tahun ke tahun sebagai negara berkembang belum cukup untuk memenangkan persaingan dalam MEA apabila 
tingkat penerapan inovasi di Indonesia masih tertinggal. Oleh sebab itu, penelitian yang akan dilakukan ini akan sangat bermanfaat bagi perusahaan, di mana dapat memberikan masukan mengenai pendekatan inovasi, khususnya pendekatan open innovation seperti apa yang dapat diterapkan perusahaan di Indonesia.

Pendekatan dalam open innovation bertujuan untuk memfasilitasi arah dari sumber informasi atau pengetahuan internal dan eksternal yang dapat digunakan dalam mengembangkan inovasi (Brant dan Lohse, 2014; Bradford, 2011; Chesbrough, 2012). Pada penelitian sebelumnya telah dijelaskan beberapa paramaeter yang digunakan dalam pendekatan open innovation, antara lain kolaborasi antar organisasi, akuisisi teknologi, penggunaan layanan $\mathrm{R} \& \mathrm{D}$ dari eksternal perusahaan, integrasi perusahaan dengan konsumen dan supplier dalam inovasi proses, hak kekayaan intelektual dan proses lisensi (Laursen dan Salter, 2006; Enkel et.al, 2009; Ebersberger et.al, 2010; Huizingh, 2011; Huang \& Rice, 2012; Vahter et.al, 2013; Armellini et.al, 2014). Faktor-faktor pendukung berkembangnya inovasi di perusahaan terdiri dari 3 yaitu $R \& D$ internal, sumber pengetahuan eksternal, dan kemampuan perusahaan mengelola pengetahuan (Huang dan Rice, 2012; Armellini, 2014). Pendekatan open innovation yang dijalankan memiliki dampak terhadap kinerja inovasi (Laursen dan Salter, 2006; Huang dan Rice, 2012; Vahter et.al, 2013; Armellini et.al, 2014). Mesipun demikian, implementasi dalam inovasi proses menghadapi lebih banyak tantangan untuk merealisasikan manfaat dari strategi open innovation daripada inovasi produk dan jasa. Ini terkait keterbatasan pada R\&D internal perusahaan dan sedikitnya kesempatan menjadikan hal tersebut komersil. Karakteristik inovasi dalam proses tersebut menghasilkan penurunan dampak investasi penelitian di dalam perusahaan dan memberikan dampak yang berlawanan dalam kemampuan perusahaan mengelola pengetahuan dalam inovasi proses. (Huang dan Rice, 2012; Armellini, 2014).

Untuk menjawab penerapan inovasi, khususnya open innovation di Indonesia, penelitian ini melakukan replikasi dari penelitian yang dilakukan oleh Huang dan Rice (2012) mengenai openness in innovation. Hal ini karena 
kontribusi penelitian ini adalah untuk mengetahui parameter dalam pendekatan open innovation yang berpengaruh terhadap kinerja inovasi, dan juga ingin mengetahui pengaruh dari sumber informasi eksternal, dan R\&D internal terhadap kinerja inovasi di perusahaan. Berdasarkan hal tersebut, penelitian Huang \& Rice (2012) yang mendekati dengan konsep penelitian ini. Penelitian tersebut mencoba mengisi kesenjangan dalam literatur open innovation melalui pengujian empiris mengenai dampak dari keterbukaan berinovasi dalam inovasi proses operasional dan manajerial, serta produk. Hasil dari penelitian tersebut mengemukakan bahwa model open innovation sangat berguna bagi perusahaan untuk mengusahakan inovasi dalam proses dan produk atau jasa. Penelitian yang dilakukan dengan sampel skala besar perusahaan-perusahaan di Australia tersebut menemukan bahwa keterbukaan pada sumber informasi eksternal, seiring waktu memacu penurunan keuntungan yang didapat sebagaimana yang diukur oleh kinerja inovasi. Selain itu, investasi dalam daya serap (absorptive capacity) telah menurunkan dampak menguntungkan pada kinerja inovasi dalam proses yang baru, tetapi tidak dalam memperkenalkan produk dan jasa baru.

Jenis replikasi yang digunakan dalam penelitian ini adalah context/methode replication. Context/methode replication adalah penelitian yang menjawab masalah yang sama dengan penelitian yang sudah dilakukan sebelumnya (penelitian yang direplikasi), namun mengambil konteks wilayah dan menggunakan metode analisis yang berbeda dengan penelitian yang direplikasi. Penelitian ini dilakukan di Indonesia dengan metode analisis data menggunakan multiple regression, mereplikasi penelitian Huang \& Rice (2012) yang dilakukan di Australia dengan metode analisis data menggunakan logistic regression.

\section{Rumusan Masalah}

Berdasarkan latar belakang yang sudah dikemukakan di atas, maka rumusan masalah dalam penelitian ini adalah:

1. Apakah ada pengaruh pendekatan open innovation terhadap kinerja inovasi di perusahaan Indonesia?

2. Apakah ada pengaruh sumber informasi dari eksternal terhadap kinerja inovasi di perusahaan Indonesia? 
3. Apakah ada pengaruh $\mathrm{R} \& \mathrm{D}$ internal terhadap kinerja inovasi di perusahaan Indonesia?

\section{Tujuan Penelitian}

Tujuan dari penelitian ini adalah untuk mengetahui pengaruh pendekatan open innovation terhadap kinerja inovasi di perusahaan Indonesia dan pengaruh faktorfaktor pendukung perkembangan inovasi terhadap kinerja inovasi di perusahaan Indonesia.

\section{Manfaat Penelitian}

Manfaat dari penelitian ini adalah sebagai berikut :

1. Manfaat Praktis. Penelitian ini bermanfaat bagi perusahaan dalam memberikan masukan upaya penerapan inovasi terutama open innovation perusahaan di Indonesia dalam kinerja inovasi. Hal ini dapat digunakan perusahaan untuk membangun keunggulan bersaing dalam menghadapi MEA. Selain itu, perusahaan juga mendapatkan masukan mengenai faktor-faktor yang mendukung perkembangan inovasi di perusahaan.

2. Manfaat Akademis. Penelitian ini bermanfaat secara akademis dalam memperkaya literatur mengenai inovasi terutama open innovation yang terkait kinerja inovasi di perusahaan Indonesia.

\section{TINJAUAN TEORI}

Inovasi Produk dan Proses

Pedoman pengukuran inovasi, Oslo

Manual (OECD / Eurostat, 2005), mendefinisikan inovasi sebagai implementasi produk atau jasa, proses, metode pemasaran, metode organisasi yang baru atau lebih baik (improved) secara signifikan, atas praktek bisnis, tempat kerja atau dalam membina hubungan eksternal. Berikut definisi menurut Oslo Manual:

- Inovasi produk adalah introduksi produk barang atau jasa yang baru atau lebih baik (improved) secara signifikan dalam hal kemampuan, kemudahan penggunaan, pemakaian komponen atau bagian produk tersebut. Inovasi produk bisa berupa perbaikan pada aspek teknis, komponen atau material suatu produk, memberi kegunaan yang lebih menyenangkan konsumen.

- $\quad$ Inovasi proses adalah implementasi dari proses produksi, metode distribusi, atau aktivitas 
penunjang yang baru atau lebih baik secara signifikan. Dapat berupa perbaikan signifikan dalam aspek teknis, peralatan dan/atau perangkat lunak.

- Inovasi pemasaran adalah pelaksanaan dari konsep atau strategi pemasaran baru yang berbeda secara signifikan dengan metode pemasaran sebelumnya dan belum pernah dijalankan sebelumnya. Inovasi ini menuntut perubahan signifikan dalam hal rancangan produk atau kemasan, penempatan produk, promosi atau penentuan harga produk. Inovasi pemasaran ditujukan untuk penanganan yang lebih baik dalam kebutuhan pelanggan, membuka pasar baru, atau posisi produk perusahaan baru di pasar, dengan tujuan untuk meningkatkan penjualan perusahaan.

- Inovasi Organisasional adalah metode baru dalam menjalankan praktik bisnis perusahaan (termasuk penerapan manajemen pengetahuan), pengaturan tempat kerja atau hubungan eksternal yang belum pernah dilakukan oleh perusahaan. Inovasi tersebut harus merupakan hasil keputusan strategis yang diambil manajemen perusahaan.
Hal ini sejalan dengan Community Innovation Survey Uni Eropa (CIS) bahwa perusahaan yang inovatif baik produk dan/atau proses-nya didefinisikan sebagai perusahaan yang mengimplementasikan inovasi pada produk atau proses, atau kegiatan inovasi produk/proses apakah masih atau sedang berlangsung atau justru ditinggalkan (CIS, 2008). Dengan demikian, penelitian ini menggunakan dasar pada klasifikasi inovasi yang dijelaskan dalam Oslo Manual (OECD Oslo Manual, 2005) sebagai inovasi produk, proses, organisasi dan pemasaran. Akan tetapi, bila merujuk pada replikasi penelitian berdasarkan penelitian Huang dan Rice (2012), inovasi yang digunakan hanya pada inovasi produk dan proses saja, di mana mereka menggabungkan inovasi organisasi ke dalam inovasi proses. Oleh karena itu, studi ini fokus pada inovasi produk, inovasi proses dan inovasi organisasi.

\section{Kinerja Inovasi}

Inovasi, tidak dapat disangkal, merupakan salah satu tuas strategis dan operasional yang paling penting untuk menciptakan keunggulan kompetitif. Studi terbaru menunjukkan bahwa 
masih ada kesenjangan yang serius antara apa

yang diharapkan oleh perusahaan, dan apa yang sebenarnya perusahaan hasilkan dari investasi dalam inovasi. Oleh karena itu, agar efektif, perlu suatu pengukuran pada faktor-faktor kritikal dalam penentu keberhasilan dan proses inovasi di perusahaan (Birchall et.al, 2011). Pengukuran dalam inovasi dapat dilihat berdasarkan pendekatan dalam inovasi, interaksi perusahaan dengan lingkungan luar dan pasar, pengembangan produk, pengelolaan proses inovasi, dan pengelolaan SDM (Lendel dan Varmus, 2013). Selain itu, Menurut Ryan (2010) pengukuran kinerja inovasi dapat dilihat dari implementasi ide-ide inovasi yang efektif dan efisien baik secara kuantitas maupun kualitas ide-ide tersebut. Hal ini terlihat pada Gambar 1 yang menunjukkan seberapa cepat dan seberapa baik ide diterapkan dan seberapa banyak nilai tambah yang dihasilkan dari inovasi.

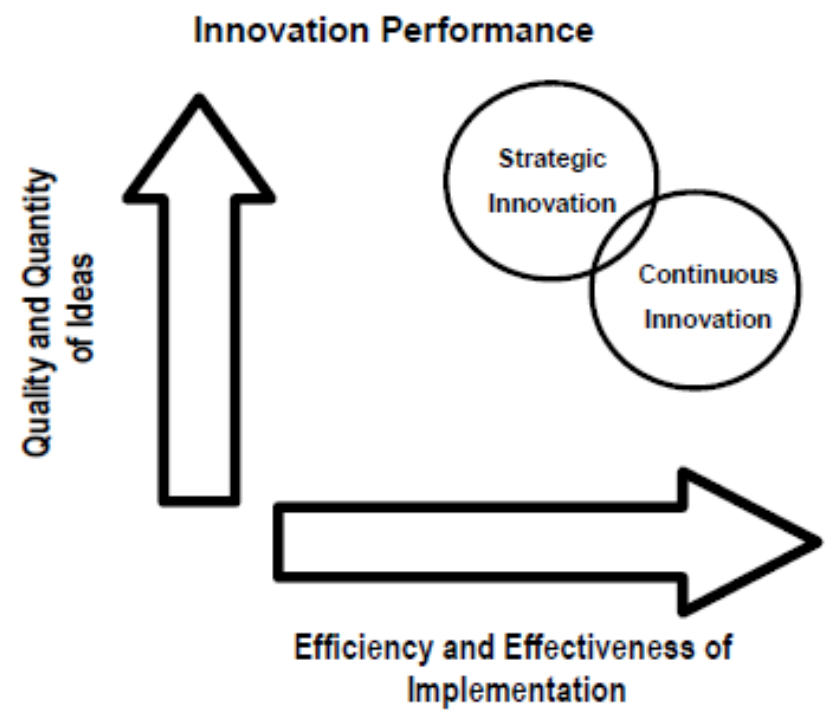

\section{Gambar 1. \\ Kinerja Inovasi (Innovation Performance)}

(Ryan, 2010)

\section{Pendekatan "Open Innovation"}

Pada perusahaan dengan praktek inovasi tertutup (closed innovation) menganut filosofi yaitu inovasi yang berhasil membutuhkan kontrol. Dengan kata lain, perusahaan harus menghasilkan ide mereka sendiri yang kemudian akan berinvestasi lebih banyak pada $R \& D$ dan merekrut sumberdaya terbaik guna mengembangkan, memproduksi, memasarkan, mendistribusikan ide tersebut ke pasar lebih dulu. Meskipun demikian, berbagai faktor, termasuk globalisasi, kemajuan teknologi informasi dan komunikasi (TIK), dan kompleksitas teknologi yang semakin meningkat, telah mengikis dasar-dasar dari 
pendekatan inovasi tertutup (Chesbrough, 2003 dalam OECD, 2008). Globalisasi menjadi pendorong utama untuk proses inovasi lebih terbuka, hal ini terlihat dari semakin banyak negara termasuk negara-negara berkembang yang telah mengembangkan kemampuan ilmu pengetahuan dan teknologi serta sumber daya (peneliti dan R\&D) secara cepat untuk menyediakan pengetahuan secara global. Faktorfaktor lain yang juga penting dalam mengikis inovasi tertutup adalah kompleksitas yang lebih besar dari produk dan jasa, pelanggan yang lebih berpendidikan dan lebih menuntut serta konvergensi teknologi (OECD 2008).

Faktor-faktor tersebut telah mendorong bisnis untuk semakin terlibat dalam kolaborasi inovasi. Pendekatan kolaboratif terhadap inovasi ini yang disebut inovasi terbuka (open innovation). Open Innovation dilihat sebagai pendekatan baru dalam melakukan inovasi, selain pendekatan inovasi sebelumnya yaitu dengan cara tradisional atau tertutup yang hanya melibatkan $\mathrm{R} \& \mathrm{D}$ dalam proses menghasilkan ide-ide untuk ditawarkan pada pasar. Ssedangkan pada paradigma Open Innovation, perusahaan mengintegrasikan ide-ide dan sumber informasi internal dan eksternal secara optimal, agar lebih efektif dalam mengelola biaya dan risiko untuk mempercepat pengembangan teknologi atau kepentingan perusahaan (Chesbrough, 2003b; Brant dan Lohse, 2014). Perusahaan menggunakan pendekatan ini kepada internal organisasi agar arus pengetahuan dapat masuk dan keluar dengan baik yang masing-masing berguna untuk mempercepat inovasi internal dan secara eksternal dapat memperluas inovasi (Chesbrough, 2006).

Open innovation dapat dianggap sebagai pendekatan yang fleksibel, yang menawarkan berbagai cara di mana ide dapat dikembangkan dan dibawa ke pasar, seperti in-licensing, outlicensing, cross-licensing, perjanjian bersama dalam $\mathrm{R} \& \mathrm{D}$, joint venture, usaha patungan, dan bahkan melalui akuisisi. Licensing yang dimaksud adalah pengaturan kontrak antara dua atau lebih pihak di mana masing-masing pihak diberikan hak guna atas teknologi, produk, penelitian, atau subjek lainnya. In licensing ditujukan untuk perusahaan yang mendapatkan hak guna, sedangkan out-licensing ditujukan untuk perusahaan yang memberikan hak guna, 
sementara cross-licensing umumnya terjadi antara perusahaan yang memegang paten atas berbagai aspek dari produk yang sama, dengan membuat perjanjian setiap perusahaan yang terlibat dapat menghindari litigasi atas sengketa pelanggaran. Perjanjian ini umumnya tergantung pada kejelasan dalam pengaturan kekayaan intelektual perusahaan (Brant dan Lohse, 2014; Gassman dan Enkel, 2004).

Menurut Gassmann dan Enkel (2004) terdapat tiga proses kegiatan inti pada open innovation, yaitu proses pertama adalah proses outside-in, proses inside-out dan terakhir proses kombinasi. Pada proses pertama yaitu outside-in, memiliki pengertian di mana perusahaan berusaha meningkatkan basis pengetahuan sendiri melalui integrasi pemasok, pelanggan dan mengakses pengetahuan eksternal yang dapat meningkatkan inovasi. Proses kedua yaitu inside-out, perusahaan mendapat keuntungan dengan membawa ide-ide ke pasar, menjual kekayaan intelektual, dan mengembangkan teknologi dengan mentransfer ide-ide ke lingkungan luar. Untuk proses yang terakhir yaitu proses kombinasi, yang menggabungkan proses outside-in dan inside-out, kemudian bekerja sebagai aliansi atau mitra dengan prinsip saling memberi dan menerima pengetahuan yang dimiliki demi kesuksesan. Ketiga proses tersebut menggambarkan strategi open innovation. Namun begitu, dalam taksonomi open innovation beberapa studi menggambarkan proses outside-in sebagai inbound open innovation dan proses inside-out sebagai outbound open innovation (Bianchi et al. 2011; Huizingh 2011).

Untuk proses outside-in, atau inbound open innovation terdapat studi yang melihat peran pemasok, pelanggan, dalam proses inovasi perusahaan dan pengaruhnya terhadap kinerja inovasi (Inauen dan Schenker-Wicki, 2011; Vergara dan Otero, 2015). Beberapa literatur empiris menjelaskan kemampuan daya serap (absorptive capacity) sebagai pilihan yang tepat sebagai mitra dalam mengakses pengetahuan eksternal, dan saling melengkapi antara $R \& D$ internal dan eksternal dalam proses inovasi (Vanhaverbeke, 2007; Flor et.al, 2013). Penelitian empiris tentang proses inside-out atau outbound open innovation menunjukkan bahwa indikator-indikator yang termasuk dalam proses outbound memiliki dampak positif terhadap 
kinerja inovasi (Kutnoven, 2011; Chesbrough dan Chen, 2015; Ji et.al, 2016). Menurut Michelino et.al (2014), praktik inbound dan outbound memiliki penyebaran yang sama dalam hal jumlah perusahaan yang mengadopsi mereka. Literatur proses kombinasi seperti yang dijelaskan oleh Gassmann dan Enkel (2004) lebih banyak di joint venture, aliansi dan jaringan, meskipun tampaknya lebih fokus pada sumber teknologi dan proses outside-in. Pemilihan pendekatan open innovation dapat disesuaikan dengan karakteristik dan proses open innovation yang akan dikembangkan di perusahaan (Gassman dan Enkel, 2004). Dengan demikian, penelitian ini mengadopsi kolaborasi antar-organisasi, akuisisi teknologi, dan R\&D eksternal (outsourcing) sebagai langkah pendekatan dalam open innovation di perusahaan (OECD 2008).

Terdapat beberapa bukti adanya hubungan antara praktik open innovation dan kinerja inovasi. Knudsen dan Mortensen (2011) menganalisis hubungan antara derajat kebebasan pada keterbukaan dan kinerja NPD. Hubungan antar-organisasi dalam pengembangan produk baru sebagai dasar untuk operasionalisasi pada praktek keterbukaan karena merupakan sumber penting dari ide dan pengetahuan untuk menjaga keterikatan pada open innovation. Penelitian ini menemukan bahwa penggunaan hubungan internal dan eksternal sangat berkorelasi dan berinteraksi satu sama lain, meskipun perusahaan yang menerapkan praktik open innovation tidak menunjukkan kinerja yang lebih baik dalam kinerja NPD. Pada kasus inovasi perusahaan agri-food di Spanyol menunjukkan bahwa dimensi open innovation yaitu sumber informasi dan kerjasama cooperation memiliki pengaruh terhadap kinerja inovasi, akan tetapi pengeluaran untuk $R \& D$ Eksternal tidak mempengaruhi dalam kinerja inovasi (Bayona-Sáez, 2013). Salge et al. (2012), memperlihatkan pada data longitudinal dan lintas sektoral dari perusahaan Jerman yang diteliti, ditemukan bahwa dari analisis ekonometrik yang dilakukan diperoleh hasil yang besar pada proses open innovation ketika perusahaan mempertahankan kapasitas internalnya dan kolaborasi lintas fungsional, sedangkan kaitan dengan pendapatan perusahaan yaitu kinerja inovasi lebih besar dihasilkan dari produk yang benar-benar baru. 


\section{Sumber Informasi Eksternal}

Reichstein dan Salter (2006) telah mengakui pentingnya berbagai sumber informasi untuk inovasi yang melibatkan hubungan pelanggan, pemasok, pesaing, lembaga penelitian, yang tidak hanya untuk keberhasilan pada inovasi produk dan juga untuk fasilitas inovasi proses. Perusahaan yang lebih terbuka terhadap sumber eksternal lebih mungkin untuk memiliki tingkat kinerja inovasi yang lebih tinggi. Keterbukaan terhadap sumber eksternal memungkinkan perusahaan untuk menarik ide-ide dari luar untuk memperdalam peluang teknologi yang tersedia bagi mereka (Laursen dan Salter, 2006).

Sumber informasi eksternal merupakan bagian dari proses outside-in (Gassman dan Enkel, 2004). Proses outside-in dan kemampuan daya serap dapat dihubungkan satu sama lain, karena memiliki fokus yang sama yaitu pada bagaimana sumber informasi eksternal dikembangkan. Pemahaman daya serap ditentukan oleh kemampuan perusahaan (dalam hal ini sumber daya menjadi dasar) dalam membangun dan mengelola antar ikatan organisasi. Kedua konsep baik outside-in dan kemampuan daya serap harus terikat satu sama lain karena berfokus pada praktek manajerial yang sama di mana keputusan manajemen dapat memperkuat kemampuan perusahaan untuk belajar dari lingkungan eksternal (Vanhaverbeke, et.al., 2007; Murovec dan Prodan, 2008).

Kemampuan daya serap dalam sumber informasi eksternal memiliki pengaruh positif terhadap inovasi produk dan proses dalam organisasi yang terlibat dalam kegiatan inovasi. Sebuah organisasi yang mampu memanfaatkan pengetahuan dari sumber informasi eksternal yang berbeda akan lebih berhasil meningkatkan fleksibilitas dalam produksi atau jasa pengiriman dan kapasitas dan mengurangi biaya tenaga kerja dan bahan-bahan atau energi per unit yang diproduksi atau transaksi. Organisasi tersebut akan lebih berhasil meningkatkan jangkauan barang atau jasa mereka, meningkatkan pangsa pasar atau pasar mereka dan meningkatkan kualitas barang dan jasa mereka (Murovec dan Prodan, 2008).

\section{R\&D Internal}

Perusahaan umumnya dapat melakukan $R \& D$ internal dan mengembangkan pengetahuan 


\section{Pengaruh Pendekatan Open Innovation terhadap Kinerja ...(Siti Fadhilah \& Julianita KS.)}

dan teknologi mereka sendiri. Adanya outsourcing pada teknologi tergantung pada kemampuan $\mathrm{R} \& \mathrm{D}$ internal perusahaan dan juga perusahaan perlu mengalokasikan sumber daya untuk program tertentu. Sebagai contoh, investasi harus dilakukan untuk karyawan $\mathrm{R} \& \mathrm{D}$, fasilitas, peralatan, dan bahan, investasi ini biasanya mahal. R\&D Internal lebih memakan waktu dan proses yang kompleks dibandingkan dengan alternatif sumber eksternal. Akan tetapi, salah satu keunggulan utama melakukan pengembangan teknologi internal itu dapat menjadi sumber keunggulan kompetitif yang berkelanjutan akibat akumulasi sumber daya yang langka (Bradford, 2011).

Jadi R\&D internal tidak perlu dihindari bila melakukan pendekatan open innovation, dengan adanya konsep keterbukaan mungkin dapat merangsang investasi riset internal untuk mencari sinergi tersebut (Chesbrough, 2006). Argumen ini dapat menjadi prinsip utama bahwa open innovation dapat berfungsi sebagai pelengkap daripada sebagai pengganti dalam kegiatan R\&D internal (Chesbrough, 2006). Berdasarkan pertimbangan tersebut, terlihat bahwa R\&D internal masih bisa memberikan keuntungan kinerja inovasi perusahaan dalam konteks open innovation.

Berdasarkan penjelasan di atas, kami mengusulkan hipotesis sebagai berikut:

H1: Pendekatan open innovation berpengaruh secara positif terhadap kinerja inovasi (baik inovasi produk dan proses).

$\mathrm{H} 2$ : Sumber informasi dari internal dan eksternal (kemampuan daya serap) berpengaruh secara positif terhadap kinerja inovasi (baik inovasi produk dan proses).

H3: R\&D Internal berpengaruh secara positif terhadap kinerja inovasi (baik inovasi produk dan proses).

Berdasarkan penjelasan di atas, maka model dari penelitian ini dapat dilihat pada gambar 2. 


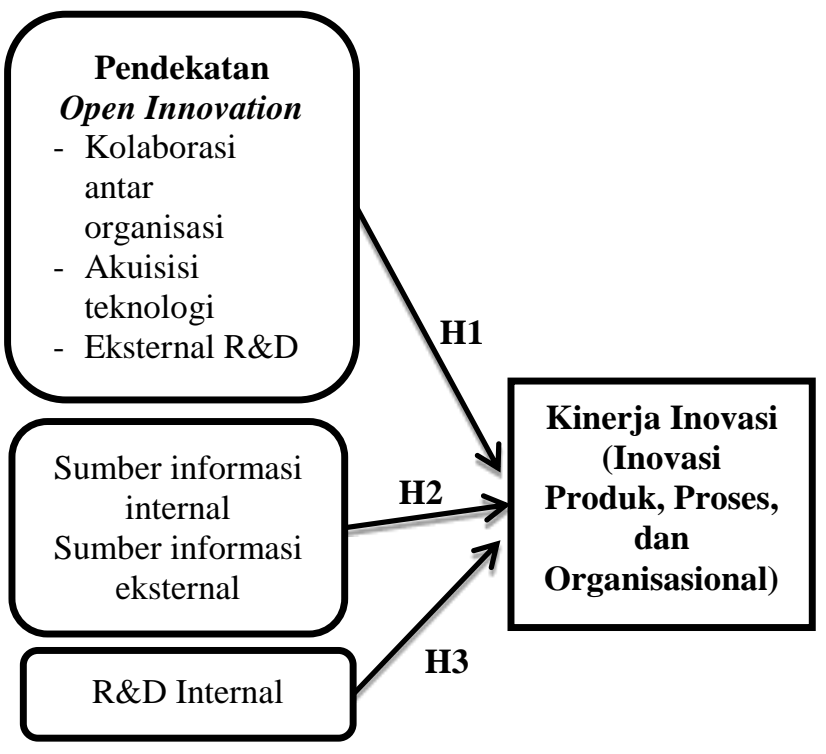

Gambar 2.

Model Penelitian Pengaruh Pendekatan Open Innovation terhadap Kinerja Inovasi Di Indonesia

\section{METODE RISET}

\section{Populasi dan Sampel}

Penelitian ini membahas secara khusus mengenai dampak open innovation pada kinerja inovasi perusahaan. Penelitian dilakukan pada tahun 2014 dengan ruang lingkup yaitu perusahaan Indonesia yang bergerak di seluruh sektor industri (baik sektor manufaktur dan jasa), yang melakukan aktivitas inovasi selama 3 tahun terakhir, yaitu tahun 2011 sampai dengan tahun 2013. Untuk sampel dalam penelitian ini menggunakan database dari PPM Manajemen yang merupakan pangkalan data yang telah diverifikasi dan cukup mewakili data perusahaan yang ada di Indonesia. Teknik pengambilan sampel melalui non probability sampling dengan cara penarikan melalui purposive sampling. Hal ini dikarenakan belum terdapat data yang jelas mengenai populasi pada penelitian ini yaitu seberapa banyak perusahaan di Indonesia yang telah berinovasi. Oleh karena itu, tidak mungkin pengambilan sampel dari populasi tersebut dilakukan secara adil dengan memberikan peluang yang sama kepada setiap anggota sebagai sampel. Jumlah sampel pada penelitian ini adalah sebanyak 230 perusahaan sebagaimana kriteria di atas.

\section{Variabel Pengukuran}

Variabel yang diukur dalam penelitian ini terdiri dari dua jenis variabel yaitu variabel yang dipengaruhi atau biasa disebut dengan Dependent Variable (DV) dan variabel bebas atau variabel yang mempengaruhi yang biasa disebut dengan Independent Variable (IV). Pada DV yang akan diukur adalah kinerja inovasi yang biasa digunakan dalam literatur inovasi yang merupakan respon skala dikotomus $(1=\mathrm{Ya}$ dan $0=$ Tidak) terhadap pertanyaan mengenai apakah perusahaan telah meluncurkan barang 
atau jasa baru dalam periode yang diteliti (Inovasi produk), kemudian pengukuran terhadap pertanyaan apakah perusahaan memperkenalkan proses operasional baru secara internal (Inovasi proses), dan yang terakhir merupakan pengukuran terhadap pertanyaan mengenai proses organisasi atau manajerial baru (Inovasi Organisasi). Kesemua pengukuran tersebut menjadi satu variabel yang diberi label Kinov (kinerja inovasi). Pada IV terdapat tiga variabel yang mempengaruhi yaitu pendekatan Open Innovation (OI) dengan mengukur mitra kerjasama dalam berinovasi (Kolaborasi), akuisisi teknologi (Akuisisi Tek), R\&D Eksternal dengan menggunakan skala pengukuran dikotomus ( $1=$ Ya dan $0=$ Tidak), kemudian sumber informasi internal dan eksternal menggunakan skala likert (1=Tidak Digunakan, 2=Rendah, $3=$ Sedang, dan 4=Tinggi), dan $\quad$ \&\&D Internal yang pengukurannya menggunakan skala dikotomus (1=Ya dan $0=$ Tidak).

\section{Metode Pengumpulan Data}

Untuk mendapatkan data yang akan diolah, dilakukan pengumpulan data dengan instrumen sebagai berikut:
1. Data primer. Peneliti melakukan pengumpulan data primer melalui kuesioner yang dibagikan kepada responden melalui sistem online dengan menggunakan survey online yaitu Qualtrics. Kuesioner pada penelitian ini diadaptasi dari Community Innovation Survey (CIS) (berdasarkan Oslo Manual oleh Organisation for Economic Co-operation and Development/OECD).

2. Data sekunder. Data ini diperoleh melalui studi kepustakaan, artikel, dan jurnal yang menyangkut masalah yang diteliti.

\section{Metode Analisis Data}

Penelitian ini menggunakan pendekatan penelitian secara kuantitatif sehingga data yang telah terkumpul melalui kuesioner akan diolah dan dianalisis menggunakan teknik analisis secara statistik, baik secara deskriptif dan inferensial. Pada analisis statistik deskriptif, penelitian ini ingin melihat nilai mean dan standar deviasi. Sedangkan analisis statistik inferensial dilakukan untuk mengetahui pengaruh antara dua variabel yaitu variabel yang dipengaruhi (DV) dengan variabel bebas (IV), 
dengan melihat korelasi dan regresi berganda pada kedua variabel tersebut.

\section{HASIL PENELITIAN DAN PEMBAHASAN}

Data yang telah terkumpul sebanyak 230 perusahaan. Akan tetapi dalam pengisian kuesioner banyak yang tidak lengkap dalam menjawab pertanyaan yang diajukan. Untuk menganalisis data diperlukan data yang valid ( $\mathrm{N}$ valid) yaitu data yang lengkap dengan semua jawaban sehingga jumlah data yang bisa terpakai untuk dapat dianalisis adalah $106(\mathrm{~N}=106)$.

Sebelum melakukan uji hipotesis, variabel-variabel yang akan digunakan dilakukan analisis statistik deskriptif dan uji korelasi, dimana hasil analisis dan pengujian dapat dilihat pada Tabel 1. Terlihat beberapa variabel berkorelasi pada tingkat level 0,05 . Akan tetapi tidak berkorelasi cukup kuat untuk dikatakan multikolinearitas, yang memiliki arti bahwa terdapat korelasi antar variabel bebas (independent) pada model regresi. Pengujian multikolinearitas dilakukan dengan melihat nilai VIF (Variance Inflation Factors) dan TOL
(Tolerance), di mana nilai VIF dan TOL yang direkomendasikan adalah VIF kurang dari 4 dan TOL lebih dari 0,1 (Hair, et.al., 2006). Untuk keperluan model dalam penelitian ini semua nilai VIF dari semua variabel independen kurang dari 4 yaitu antara 1,026-1,690 dan nilai TOL diatas 0,1 . Oleh karena itu, dapat disimpulkan bahwa tidak ada kekhawatiran terjadi multikolinearitas dalam data.

Analisis berikutnya adalah pengujian hipotesis pada penelitian ini dengan menggunakan analisis regresi hierarki dengan $\mathrm{N}=106$, Pengujian hipotesis dibagi kedalam 3 model yaitu, model 1 menguji pengaruh pendekatan open innovation (kolaborasi, akusisi teknologi, dan R\&D Eksternal) terhadap inovasi; model 2 menambahkan variabel sumber informasi internal \& eksternal terhadap inovasi; serta model 3 menambahkan R\&D Internal terhadap inovasi. 
Tabel 1.

Statistik Deskriptif dan Korelasi

\begin{tabular}{|c|c|c|c|c|c|c|c|}
\hline Variabel & 1 & 2 & 3 & 4 & 5 & 6 & 7 \\
\hline 1. Kolaborasi & & & & & & & \\
\hline 2. R\&D Eksternal & 0,156 & & & & & & \\
\hline 3. Akuisisi Teknologi & 0,106 & 0,132 & & & & & \\
\hline 4. Smber Informasi Internal & $0,478 * *$ & $0,287 * *$ & $0,338 * *$ & & & & \\
\hline 5. Sumber Informasi Eksternal & $0,410 * *$ & $0,418 * *$ & $0,173 *$ & $0,491 * *$ & & & \\
\hline 6. R\&D Internal & $0,202 *$ & $0,278 * *$ & $0,325 * *$ & $0,330 * *$ & $0,273 * *$ & & \\
\hline 7. Inovasi & $0,347 * *$ & $0,240 * *$ & $0,396 * *$ & $0,310 * *$ & $0,278 * *$ & $0,432 * *$ & \\
\hline Mean & & & & 3,2358 & 2,6289 & & 5,7264 \\
\hline Standard Deviation & & & & 1,00997 & 0,72006 & & 1,87988 \\
\hline Cronbach Alpha & 0,63 & 0,618 & 0,61 & 0,555 & 0,581 & 0,604 & 0,686 \\
\hline
\end{tabular}

Pengujian hipotesis pada Model 1 menunjukkan hasil yang signifikan saat nilai $\mathrm{F}(3,102)=12,714$ dengan $\mathrm{p}<0,01$, ini menunjukkan pengaruh varibel independen terhadap variabel dependen sebesar 27,2\%, Hal ini berarti mendukung $\mathrm{H} 1$ yaitu terdapat pengaruh pendekatan open innovation terhadap kinerja inovasi perusahaan di Indonesia dan model 1 mampu menjelaskan varian dari variabel dependen sebesar 27,2\%, Masing-masing variabel pendekatan open innovation memberikan pengaruh berbeda terhadap kinerja inovasi. Kolaborasi dengan pihak diluar perusahaan dan akuisisi teknologi memiliki pengaruh yang signifikan, sedangkan R\&D Eksternal tidak memiliki pengaruh yang signifikan terhadap kinerja inovasi. Hal ini ditunjukkan dari signifikansi nilai t ( $\mathrm{t}$-value) pada masing-masing variabel. Nilai t pada kolaborasi dan akuisisi teknologi sebesar 3,340 dan 4,040 berada pada level $\mathrm{p}$-value $<0,01$, sedangkan nilai t pada $R \& D$ eksternal adalah 1,737 dengan $p-$ value $>0,05$.

Model 2 secara keseluruhan menunjukkan hasil yang signifikan dengan nilai $\mathrm{F}(5,100)=7,557$ dengan $\mathrm{p}<0,01$, kemampuan model 2 menjelaskan varian dari variabel dependen sebesar 27,4\%, Namun apabila dilihat perubahan nilai $\mathrm{F}$, maka penambahan variabel pada model 2 ternyata tidak memberikan pengaruh yang signifikan, di mana $\mathrm{F}$ change $(0,142)$ memiliki $p>0,05$. Variabel yang ditambahkan pada model 2 ini adalah sumber informasi internal dan eksternal dan masingmasing memiliki nilai t sebesar 0,046 dan 0,495 dengan p-value $>0,05$. Akan tetapi, kemampuan variabel sumber informasi internal dan eksternal pada model 2 untuk menjelaskan kinerja inovasi sangat kecil yaitu hanya sebesar $0,2 \%$, Hal ini berarti sumber informasi internal dan eksternal tidak berpengaruh terhadap kinerja inovasi di perusahaan Indonesia, dan tidak mendukung H2. 
Tabel 2.

Hasil Analisis Regresi Hierarki

\begin{tabular}{lccc}
\hline DV: Kinerja Inovasi & Model 1 & Model 2 & Model 3 \\
\hline Langkah 1: Pendekatan Open Innovation & $0,287^{* *}$ & $0,266^{* *}$ & $0,252^{*}$ \\
$\quad$ Kolaborasi & 0,150 & 0,130 & 0,085 \\
R\&D Eksternal & $0,346^{* *}$ & $0,340^{* *}$ & $0,275^{* *}$ \\
$\quad$ Akuisisi Teknologi & & & \\
Langkah 2: & & 0,005 & $-0,033$ \\
$\quad$ Sumber informasi internal & & 0,053 & 0,034 \\
$\quad$ Sumber informasi eksternal & & \\
Langkah 3: & 0,272 & 0,274 & $0,270^{* *}$ \\
$\quad$ R\&D Internal & & 0,002 & 0,333 \\
Model R & & $7,557^{* *}$ & $0,058^{* *}$ \\
Change in $\mathrm{R}^{2}$ & $12,714^{* *}$ & $8,222^{* *}$ \\
Model F & & & \\
\hline
\end{tabular}

Nilai yang dicantumkan merupakan nilai dari Standardize Coefficient (Beta) $(\mathbf{N}=106)$ $* \mathbf{p}<0,05 ; * * \mathbf{p}<0,001$

Pada model 3, pengolahan data menunjukan hasil yang signifikan dengan $\mathrm{F}$ $(6,99)=8,222$ dengan $\mathrm{p}<0,01$. Kemampuan model 3 menjelaskan varian dari variabel dependen sebesar $33,3 \%$. Penambahan variabel R\&D Internal yang dilakukan pada model 3 ternyata memberikan pengaruh yang cukup signifikan dengan perubahan nilai $\mathrm{F}$ change $(8,657)$ yang memiliki $\mathrm{p}<0,01$. Pengaruh yang diberikan variabel $R \& D$ Internal yang cukup signifikan ditandai dengan nilai t sebesar 2,942 dengan p-value <0,01. Kemampuan variabel R\&D Internal menjelaskan kinerja inovasi sebesar 5,8\%, hasil tersebut menunjukkan bahwa
R\&D Internal memiliki pengaruh terhadap kinerja inovasi di perusahaan Indonesia

\section{KESIMPULAN DAN SARAN}

Penelitian ini mencoba untuk melihat pengaruh pendekatan open innovation terhadap kinerja inovasi perusahaan di Indonesia. Hasil penelitian ini mengkonfirmasi penelitian sebelumnya yang dilakukan oleh Huang \& Rice (2012) bahwa pendekatan open innovation memiliki pengaruh terhadap kinerja inovasi di perusahaan. Penelitian ini merupakan replikasi dari penelian Huang \& Rice (2012) yang dilakukan dengan konteks wilayah dan metode yang berbeda. Hasil dari penelitian 
yang dilakukan, mendukung hasil penelitian Huang \& Rice (2012).

\section{Implikasi untuk penelitian selanjutnya}

Pendekatan open innovation dan R\&D Internal memberikan pengaruh signifikan terhadap kinerja inovasi di perusahaan Indonesia, sedangkan R\&D eksternal tidak berpengaruh signifikan. Sumber informasi internal dan eksternal tidak memberikan pengaruh yang signifikan terhadap kinerja inovasi perusahaan di Indonesia.

Hasil tersebut dapat disebabkan karena di Indonesia masih sangat sedikit perusahaan yang melibatkan hubungan pelanggan, pemasok, pesaing, lembaga penelitian sebagai sumber informasi untuk perusahaan dalam upaya meningkatkan kinerja inovasi. Hal ini dapat dilihat dari studi yang dilakukan oleh CIC (Center of Innovation and Colaboration) (2013) bahwa mitra dalam aktivitas inovasi dengan kompetitor, R\&D eksternal, universitas, dan pemerintah memiliki nilai yang rendah yaitu hanya berkisar $1.9 \%-6.8 \%$. Studi sebelumnya pun telah mengakui pentingnya berbagai sumber informasi untuk inovasi yang melibatkan hubungan pelanggan, pemasok, pesaing, lembaga penelitian, yang tidak hanya untuk keberhasilan pada inovasi produk dan juga untuk fasilitas inovasi proses (Reichstein dan Salter, 2006). Selain itu pada penerapan open innovation, sangat penting bagi perusahaan dalam menyerap sumber informasi baik dari internal eksternal dalam peningkatan kinerja inovasi perusahaan.
Pengetahuan yang didapatkan dari lingkungan eksternal dapat berguna dalam praktek manajerial di mana keputusan manajemen dapat memperkuat kemampuan perusahaan dalam belajar mengenai inovasi secara terbuka atau hal ini dikenal dengan proses outside-in (Vanhaverbeke, et.al., 2007; Murovec dan Prodan, 2008). Perusahaan yang lebih terbuka terhadap sumber eksternal juga lebih mungkin untuk memiliki tingkat kinerja inovasi yang lebih tinggi. Keterbukaan terhadap sumber eksternal memungkinkan perusahaan untuk menarik ideide dari luar untuk memperdalam peluang teknologi yang tersedia bagi mereka (Laursen dan Salter, 2006). Hal ini juga yang mungkin menjadi salah satu penjelasan masih rendahnya peringkat inovasi di Indonesia dibandingkan negara-negara lain terutama di Asia dan Australia.

\section{Implikasi untuk penerapan}

Inovasi sangat penting karena dapat berperan untuk mengembangkan keunggulan bersaing (Hana, 2013; Brem et.al, 2016; Farhas et.al, 2016). Inovasi dalam bisnis dapat dikembangkan dengan pendekatan yang spesifik, pendekatan inovasi dapat dilakukan oleh para manajer secara komprehensif dari sudut manajemen umum yang kemudian dilanjutkan dengan penerapan dua program perubahan, antara lain dengan program perubahan yang sifatnya menantang seperti mendesain proses, tanggung jawab dan praktik yang baru, dan program perubahan yang bersifat individu seperti perubahan dalam mindset, emosi, dan nilai-nilai. Perusahaan juga mengambil peran dalam 
program perubahan yaitu dengan memberikan kompetensi yang dibutuhkan, pengembangan diri berkelanjutan, dan hal yang paling penting adalah kepemimpinan dari atas dan semua level mengelola inovasi dengan sistematis dan berkelanjutan (Vila dan MacGregor, 2010). Saat ini, open innovation lebih banyak diterapkan oleh perusahaan dalam berinovasi, seperti IBM, Intel Philips, Unilever, dan Procter \& Gamble karena dunia bisnis sudah lebih terbuka dan sangat kompetitif, sehingga perusahaan perlu lebih inovatif dan kreatif untuk menarik pelanggan (Chesbrough, 2012).

Penelitian ini memberikan masukan kepada perusahaan mengenai penerapan pendekatan open innovation di Indonesia. Kolaborasi antara perusahaan, akuisisi teknologi, dan R\&D internal memiliki pengaruh pada kinerja inovasi. Penerapan kolaborasi antar perusahaan misalnya kolaborasi antar perusahaan telekomunikasi dengan institusi pendidikan untuk menciptakan produk dan proses yang inovatif, selain itu sebagai contoh dapat dilihat pada perusahaan Samsung yang berkolaborasi dengan startups. Akusisi teknologi dengan mengadaptasi teknologi terbaru yang dapat bermanfaat bagi proses maupun produk yang dihasilkan, hal ini juga dilakukan oleh Samsung dengan melakukan akuisis teknologi dari perusahaan IoT yang bernama SmarThings untuk mendapatkan platform IoT tanpa harus menghabiskan uang, dan yang lebih penting, waktu untuk R\&D. Kolaborasi dan akuisi yang dilakukan oleh Samsung bertujuan untuk mendapatkan keuntungan dari berbagai inovasi yang telah dihasilkan oleh perusahaan-perusahaan kecil. Perusahaan-perusahaan ini sering memiliki produk yang dapat melengkapi atau diintegrasikan ke produk Samsung sendiri, menciptakan nilai bagi kedua belah pihak. Di sisi lain, perusahaan yang bertujuan untuk inovasi baru tentunya membutuhkan investasi yang tinggi dan lebih baik diinvestasikan atau diakuisisi. Jadi, titik pembelajaran utama dari kasus Samsung adalah bahwa berbagai jenis perusahaan pada berbagai tahap masa hidup menawarkan berbagai kemungkinan berbeda dalam pendekatan open innovation, sehingga perlu mengidentifikasi metode yang paling sesuai dengan berbagai jenis peluang dalam berinovasi (Morikawa, 2016). Untuk penerapan $R \& D$ internal bergantung pada kemampuan R\&D perusahaan dan juga mengharuskan perusahaan untuk mengalokasikan sumber daya. Sebagai contoh, investasi harus dilakukan untuk karyawan $R \& D$, fasilitas, peralatan, dan material. Investasi pada R\&D internal umumnya mahal dan dapat menjadi proses yang memakan waktu dan rumit dibandingkan dengan alternatif sumber eksternal. Salah satu keuntungan utama dari melakukan 
pengembangan teknologi internal adalah dapat menjadi sumber keunggulan kompetitif yang berkelanjutan karena akumulasi sumber daya yang langka (Bradford, 2011).

Perhatian pada ketiga hal tersebut dapat membantu perusahaan meningkatkan kinerja inovasi. Di Indonesia, sumber informasi internal dan eksternal tidak berpengaruh signifikan yang diasumsikan karena masih minimnya keterlibatan pelanggan, pemasok, pesaing, lembaga penelitian sebagai sumber informasi bagi perusahaan. Namun, aspek ini perlu diperhatikan untuk masa yang akan datang karena perusahaan yang lebih terbuka terhadap sumber eksternal juga lebih mungkin untuk memiliki tingkat kinerja inovasi yang lebih tinggi. Keterbukaan terhadap sumber eksternal memungkinkan perusahaan untuk menarik ide-ide dari luar untuk memperdalam peluang teknologi yang tersedia bagi mereka (Laursen dan Salter, 2006).

\section{Batasan dan Peluang Penelitian}

Penelitian ini memiliki keterbatasan yaitu masih terbatasnya literatur tentang open innovation khususnya penelitian yang dilakukan di negara berkembang dan khususnya Indonesia. Pada instrumen yang digunakan merupakan instrumen yang diadaptasi sehingga mungkin saja terdapat perbedaan makna dan budaya dan terjadi perbedaan interpretasi.

Studi di masa depan dapat menggali data tidak hanya berhenti pada pengaruh kepada kinerja inovasi tetapi dampak kepada perusahaan dalam hal ini kinerja perusahaan, di mana kinerja inovasi bisa menjadi moderasi dari pendekatan open innovation kepada kinerja perusahaan, dengan menambahkan variabel kontrol seperti usia perusahaan dan jumlah karyawan. Selain itu, studi lanjutan dapat juga berfokus pada perbedaan pengaruh dan adopsi pendekatan open innovation dari perusahaan besar dan UKM.

Hal ini dapat digali tidak hanya dengan instrumen kuesioner tetapi bisa juga melalui wawancara atau observasi. Selain itu, penambahan teknik dalam pengumpulan data tersebut dapat menjadi akses untuk mendapatkan penjelasan mengenai peyebab perusahaan tidak melibatkan pihak-pihak dalam lingkungan eksternal sebagai sumber informasi guna meningkatkan kinerja inovasi. Penelitian selanjutnya juga dapat menggunakan metode pengolahan data yang berbeda misalkan dengan menggunakan regresi logistik dari variabel yang digunakan sehingga dapat memperkaya literatur dan kajian dalam penerapan open innovation dalam negara berkembang khususnya Indonesia. 


\section{DAFTAR PUSTAKA}

Armellini, F., Kaminski, P. C., Beaudry, C. (2014). The Open Innovation Journey in Emerging Economies: An Analysis of the Brazilian Aerospace Industry, Journal Aerospace Technology Management, 6 (4), 462-474. DOI: 10.5028/jatm.v6i4.390

Bayona-Sáez, C. García-Marco, T., Sanchez-García, M. (2013). The Impact of Open Innovation on Innovation Performance: The Case of Spanish Agri-Food Firms. Woodhead Publishing Series in Food Science, Technology and Nutrition, 74-94. DOI: 10.1533/9780857097248.1.74

Birchall, D., Chanaron, J. J., Tovstiga, G., Hillenbrand, C. (2011). Innovation Performance Measurement: Current Practices, Issues and Management Challenges. International Journal of Technology Management, 56 (1), 1-20. DOI: 10.1504/ijtm.2011.042492

Bogliacino, F,, Perani, G,, Pianta, M, dan Supino, S, (2009), Innovation in developing countries, The evidence from innovation surveys, Paper for the FIRB conference, Diunduh dari http://www,kites, unibocconi,it/wps/allegatiCTP/Bogliacio final,pdf

Bradford University School of Management, (2011), Open Innovation Approaches An Exploratory Study. https://d298t4b8zukb44.cloudfront.net/media/bic/knowledge_base/documents/OI\%20LDN3.pdf.

Brant, J. Dan Lohse, S. (2014). The Open Innovation Model. ICC (International Chamber Of Commerce) Innovation and Intellectual Property Research Paper, No. 2. Diunduh dari SSRN: https://ssrn.com/abstract=2426097

Brem, A., Maier, M., Wimschneider, C. (2015). Competitive Advantage through Innovation: The Case of Nespresso. European Journal of Innovation Management, 19, 133-148. DOI: 10.1108/EJIM-052014-0055

Center Of Innovation and Collaboration (CIC). (2013). Riset Praktik Inovasi Perusahaan Di Indonesia. Executive Summary. PPM Manajemen. Jakarta

Cheng, C. C. J., Yang, C.-L. Dan Sheu, C. (2014). The Link between Eco-Innovation and Business Performance: A Taiwanese Industry Context. Journal of Cleaner Production, 64, 81-90. DOI: 10.1016/J.Jclepro.2013.09.050

Chesbrough, H, (2003b), The Era of Open Innovation, MIT Sloan Management Review, Spring, 35 - 41

Chesbrough, H, W, (2006), Open Innovation: A New Paradigm for Understanding Industrial Innovation, In: H, W, Chesbrough, W Vanhaverbeke, and J, West, (eds), Open Innovation: Researching a New Paradigm, Oxford University Press,

Chesbrough, H. (2012). Open Innovation Where We've Been and Where We're Going. ResearchTechnology Management, 55. DOI: 10.5437/08956308X5504085 
Pengaruh Pendekatan Open Innovation terhadap Kinerja ...(Siti Fadhilah \& Julianita KS.)

Chesbrough, H., dan Chen, E. L. (2015). Using Inside-Out Open Innovation to Recover Abandoned Pharmaceutical Compounds. Journal of Innovation Management, 3, (2) 21-32. Diunduh dari ISSN 2183-0606 http://www.open-jim.org

Ebersberger, B., Bloch, C., Herstad, S. J., Velde, E. V. D. (2010). International Journal of Innovation and Technology Management, 9 (6), 1-22. DOI: 10.1142/S021987701250040X

Enkel, E., Gassman, O., Dan Chesbrough, H. (2009). Open R\&D And Open Innovation: Exploring The Phenomenon. R\&D Management 39, 4, 311-316. DOI: 10.1111/J.1467-9310.2009.00570.X

Farhas, R.J., Samsir, Restuti, S. (2016). Membangun Keunggulan Bersaing Melalui Inovasi, Manajemen Pengetahuan Dan Orientasi Pasar (Studi Pada Usaha Mikro Produk Makanan Khas Riau Di Kota Pekanbaru). Jurnal Tepak Manajemen Bisnis, 8, No.1. Diunduh dari https://ejournal.unri.ac.id/index.php/jtmb/article/download/4325/4149

Flor, M. L., Alfaro, J. A., Zarco, H., Oltra, M. (2013). Inbound Open Innovation, Absorptive Capacity and Innovation Performance: An Empirical Research on Spanish Firms. Paper. DRUID Celebration Conference. Barcelona

Gassmann, O,, dan Enkel, E, (2009), Towards a Theory of Open Innovation: Three Core Process Archetypes, Institute of Technology Management, University of St, Gallen, Switzerland,

Global Innovation Index, (2015), GII 2014 report, Diunduh dari https://www,globalinnovationindex,org/content,aspx?page=gii-full-report-2014

Hamdani, J. Dan Wirawan, C. (2012). Open Innovation Implementation To Sustain Indonesian Smes. Economics and Finance, 4, 223 - 233. DOI: 10.1016/S2212-5671(12)00337-1

Hana, U. (2013). Competitive Advantage Achievement through Innovation and Knowledge. Journal of Competitiveness, 5, 82-96. DOI: 10.7441/joc.2013.01.06

Huang, F,, dan Rice, J, (2012), Openness in product and process innovation, International Journal of Innovation Management, 16, 4. DOI: 10.1142/S1363919612003812

Huizingh, E. K.R.E. (2011). Open Innovation: State Of The Art And Future Perspectives. Technovation, 31 (1), 2-9. DOI: 10.1016/j.technovation.2010.10.002

Hurley, R.F., Hult, G.T.M. dan Knight, G.A. (2003). Innovativeness: Its Antecedents and Impact On Business Performance, Industrial Marketing Management, 33, 429-38. DOI: 10.2307/1251742

Inauen, M., Dan Schenker-Wicki, A. (2011). The Impact of Outside-In Open Innovation on Innovation Performance. European Journal of Innovation Management, 14 (4), 496-520, DOI: $10.1108 / 14601061111174934$

Ji, H. Y., Li, J., Lan, C. F, Feng, D., Wang, Jin, Y. S. (2016). Outbound Open Innovation for Enhanced Innovation Performance: An Empirical Study Based On BTB Enterprises In China. International 
Journal of U- And E- Service, Science and Technology, 9 (5), 309-320. DOI: 10.14257/ijunesst.2016.9.5.28

Jiménez, D.J. Dan Sanz-Valle, R. (2010). Innovation, Organizational Learning, and Performance. Journal of Business Research, 64, 408- 417. DOI: 10.1016/j.jbusres.2010.09.010

Kutnoven, 2011; Strategic Application of Outbound Open Innovation. European Journal of Innovation Management, 14 (4) 460-474. DOI: 10.1108/14601061111174916

Knudsen, P., Mortensen, B. (2011). Some Immediate But Negative Effects Of Openness On Product Development Performance, Technovation, 31, 1, 54,64,

Laursen, K,, dan Salter, A, (2006), Open for Innovation: The Role of Openness in Explaining Innovation Performance among U,K, Manufacturing Firms, Strategic Management Journal, Vol,27, pp, 131150

Lendel, V. dan Varmus, M. (2013). Evaluation of the Innovative Business Performance. Social and Behavioral Sciences, 129, 504 - 511. DOI: 10.1016/J.Sbspro.2014.03.707

Michelino, F., Caputo, M., Cammarano, A., Lamberti, E. (2014). Inbound and Outbound Open Innovation: Organization and Performances. Journal Technology Management Innovation, 9 (3), 65-82. DOI: 10.4067/S0718-27242014000300005

Morikawa, M., (2016). 16 Examples Of Open Innovation - What Can We Learn From Them? Diunduh Dari https://www.viima.com/blog/16-examples-of-open-innovation-what-can-we-learn-fromthem

Murovec, N., dan Prodan, I, (2008), The Influence of Organizational Absorptive Capacity on Product and Process Innovation, Research paper, Organizacija, 41 (2)

Muzamil dan Ginting, G. (2015). A Strategic Open Innovation Model: Productivity Inprovement In Small Medium Industries/Smis (Indonesian Case). Asia Pasific Journal of Advance Business and Social Studies, 1 (1). ISBN (Ebook): 9780994365675

Ryan, A. (2010). Innovation Performance. Diunduh dari http://www.managedinnovation.com/media/uploadedfiles/1138769716171-9707.pdf

OECD. (2005). Oslo Manual: Proposed Guidelines for Collecting and Interpreting Technological Innovation Data, Paris.

OECD. (2008). Open Innovation in Global Networks, OECD Publishing.

OECD. (2012). Innovation for Development, OECD Publishing.

Salge, T,O,, Bohné, T,M, Farchi, T, Piening, E,P, (2012). Harnessing the Value of Open Innovation: The Moderating Role of Innovation Management. International Journal of Innovation Management, 16, (3). DOI: $10.1142 / \mathrm{S} 1363919612400051$ 
Pengaruh Pendekatan Open Innovation terhadap Kinerja ...(Siti Fadhilah \& Julianita KS.)

Vahter, P., Love, J. H., dan Roper, S. (2013). Openness And Innovation Performance: Are Small Firms Different?. Journal of Industry and Innovation, 21, 7-8. DOI: 10.1080/13662716.2015.1012825

Vanhaverbeke, W,, Cloodt, M,, dan Van de Vrande, V, (2007), Connecting absorptive capacity and open innovation, Working Paper. DOI: 10.2139/ssrn.1091265

Vanhaverbeke, W., Chesbrough, H., Dan Joel West. (2014). New Frontiers in Open Innovation, Chapter: 15: Surfing the New Wave of Open Innovation Research. Book. Publisher: Oxford University Press, 281-294

Vergara, L. F., Dan Otero, J. P. (2015). The Impacts of Open Innovation Strategies On Innovative Performance: The Case Of Colombian Food And Beverage Firms. International Economic Meeting, 2 (1). Diunduh dari https://hrcak.srce.hr/161606

Worlbank,org, (2014), Diunduh dari http://data,worldbank,org/sites/default/files/wdi-2013-ch4,pdf 